\title{
O poder da caneta: a Medida Provisória no processo legislativo estadual
}

\begin{tabular}{c} 
Paolo Ricci \\
Departamento de Ciência Política \\
Universidade de São Paulo \\
Fabricio Tomio \\
Departamento de Direito Público \\
Universidade Federal do Paraná \\
\hline \hline
\end{tabular}

Resumo: A Medida Provisória (MP) brasileira é um dos instrumentos legislativos mais poderosos nas mãos do Presidente da República para alterar unilateralmente o status quo. Apesar de o judiciário ter reconhecido a competência dos governadores para instituir e adotar a MP, esta existe apenas em seis estados. $\mathrm{O}$ artigo procura explicar a não adoção deste instrumento legislativo pela maioria dos estados. Enfatiza-se a escassa ou marginal relevância que é dada à MP pelo governador nos seis casos que a adotaram. Defende-se, aqui, que os governadores, diferentemente dos presidentes, não necessitam de mais um instrumento legislativo ou da ampliação da delegação de prerrogativas legislativas para garantir sua agenda frente a seus respectivos legislativos, já que com ou sem poder de decreto estadual os governadores controlariam a já limitada agenda decisória nos estados.

Palavras-chave: medida provisória; Assembleias legislativas estaduais; relação executivo-legislativo; decreto-lei; governadores

Abstract: The Brazilian Provisional Measure (MP) is one of the most powerful legislative instruments in the hands of the President to unilaterally change the status quo. Although the judiciary (STF) has recognized the competence of Governors to establish and adopt the MP only six states attribute the prerogative to edit MP until 2010. This article seeks to explain the non-adoption of this legislative instrument by most states emphasizing the low or marginal relevance that is given to the MP by the Governor in the six cases that adopted it. It is argued here that the Governors, unlike Presidents, do not require another legislative instrument or expanding the delegation of legislative powers to ensure their legislative agenda forward their respective State Legislative Assemblies, because with or without decree power the State Governors would control the limited decisional agenda in the states.

Keywords: Provisional Measure (MP); State Legislative Assemblies; Executive-Legislative relationship; decree power; Governors 
OPINIÃO PÚBLICA, Campinas, vol. 18, no 2, novembro, 2012, p. 255-277

\section{Introdução ${ }^{1}$}

Os Constituintes, em 1988, conferiram ao Presidente da República o poder de decreto. O estatuto da Medida Provisória (MP) substituiu o Decreto-Lei (DL) do período constitucional instituído pelo regime militar, atribuindo ao executivo federal um instrumento legislativo capaz de alterar o status quo no momento de sua edição. Apesar de indicar uma continuidade institucional, a MP apresenta um grau de delegação muito menor do que o decreto presidencial do regime anterior. Isso em virtude da necessária manifestação do Congresso para a conversão final da MP em lei e da perda de vigência da MP pela ausência de manifestação dos parlamentares em decorrência do esgotamento de seu prazo constitucional. Além disso, em princípio, a edição de MP ocorreria apenas em caráter emergencial (casos de relevância e urgência), sendo também limitada quanto ao escopo normativo². Entretanto, as constantes reedições de MPs, que se seguiram à promulgação da Constituição de 1988, sem o pronunciamento formal do legislativo e sem a perda de seus efeitos, quando decorrido o prazo de sua vigência, indicaram uma continuidade incidental das prerrogativas presidenciais do regime militar. Um processo que foi modificado pelo Congresso Nacional, em 2001, ampliando e explicitando as restrições à edição de MP pelo executivo na Emenda Constitucional (EC) 32 de $2001^{3}$.

0 tema da delegação de funções legislativas ao executivo brasileiro tem sido amplamente explorado pelos estudiosos que analisam o arranjo institucional de 1988. Se alguns o exploraram sob o prisma da tensão existente nas relações entre executivo e legislativo (PESSANHA, 2000), ressaltando, sobretudo, as perdas de prerrogativas do Congresso Nacional como órgão legislador (DINIZ, 1996), outros preferiram enfatizar o fenômeno das MPs à luz da delegação de funções legislativas (AMORIM NETO e TAFNER, 2002; FIGUEIREDO e LIMONGI, 1999). Para além dos diferentes enfoques conferidos ao tema, é inegável o fato de que todos os estudiosos limitaram-se a abordá.lo destacando o funcionamento da MP no âmbito federal, deixando de lado a análise do mesmo mecanismo no âmbito subnacional. A razão disso é aparentemente simples e, de certa forma, razoavelmente justificável. Atualmente, apenas seis estados reproduziram em suas constituições estaduais a MP para os seus governadores. Trata-se de Acre, Piauí, Santa Catarina, Tocantins, Maranhão e Paraíba. Ou seja, o número limitado de casos justificaria a pouca atenção dada para o instrumento legal da MP no âmbito subnacional. Embora o dado seja incontestável, em nosso entender, o verdadeiro problema reside no fato de que se deixa de compreender o aspecto peculiar da ausência do mesmo instrumento nos estados. Ou seja, dada a

\footnotetext{
${ }^{1}$ Uma primeira versão deste artigo foi apresentada no encontro anual da Latin American Studies Association (LASA), Toronto, Canada, 6.9 outubro de 2010 com o título Executive Decree Power (Provisional Measures) and State Decision Process in Brazil: a comparative study of the delegation of legislative powers and decision-making in the Brazilian. Agradecemos aos comentários de Timothy Power, Barry Ames, Daniel Epstein e Reynaldo Rojo-Mendoza.

2 O Art. 58 da Constituição de 1967 atribuía ao Presidente da República a capacidade de expedir decretos com força de lei em casos de urgência ou de interesse público relevante. Além disso, o Art. 54 também atribuía à Presidência o direito de propor projetos de lei sobre qualquer matéria que, acrescidos da solicitação de urgência, deveriam ser apreciados em até 90 dias pela Câmara e pelo Senado, ou em até 40 dias em sessão conjunta do Congresso Nacional. Esgotados esses prazos, caso não houvesse deliberação, os projetos seriam considerados aprovados. Por outro lado, na Constituição de 1988, a aprovação de matéria por decurso de prazo é inexistente e a delegação ao Presidente das Medidas Provisórias (MP), em caso de relevância e urgência, perdia a eficácia legislativa caso o Congresso não a convertesse em lei no prazo de trinta dias (Art. 62).

3 Essa delegação foi modificada e restringida pela Emenda Constitucional (EC) 32 de 2001 que impediu explicitamente a reedição de MP, limitou o escopo normativo, atribuiu às duas casas o juízo sobre o acolhimento dos pressupostos constitucionais e ampliou o prazo de vigência da MP para até 120 dias $(60+60)$. Para uma reconstrução das etapas que levaram o legislador a mudar as regras da edição das MPs no Congresso Nacional ver o trabalho de Machiaveli (2009). A respeito dos efeitos produzidos pela mudança ver, além da mesma autora, o trabalho de Pereira et al (2008).
} 
RICCI, P.; TOMIO, F. O poder da caneta: a Medida Provisória no processo...

centralidade da MP para o âmbito federal, vista como "o instrumento legislativo mais poderoso à disposição do Executivo já que garante ao presidente o poder unilateral para alterar o status quo" (FIGUEIREDO e LIMONGI, 2007, p. 152), como se explicaria a não adoção desse instrumento legislativo pela maioria dos estados? Este artigo visa responder a esta pergunta. Em particular, nosso argumento é que os governadores, diferentemente dos presidentes, não necessitam de um instrumento legislativo a mais para se garantir frente a seus respectivos legislativos, dado que, com ou sem poder de decreto estadual, os governadores controlariam a já limitada agenda decisória nos estados.

Encontrar evidências para o escasso sucesso que a MP teve nos estados não é tarefa fácil. Tratar-se-ia de investigar as razões de uma não decisão, isto é, mais precisamente, dos fatores que levaram o constituinte estadual a não prever a MP em seus estados. Para encontrar evidências que suportem nossa hipótese adotamos uma abordagem pouco explorada pela ciência política brasileira e que vem crescendo e se desenvolvendo nos últimos anos no exterior. Trata-se da abordagem do tipo quase-experimento ${ }^{4}$. Os quase-experimentos carecem de distribuição aleatória ou grupo controle que caracteriza os estudos experimentais, mas ainda assim não são estudos observacionais. Isso porque a característica distintiva do quase-experimento é a de definir os grupos de tratamento e controle "como se" a seleção fosse feita de forma aleatória (DUNNING, 2008). De acordo com a literatura, um tipo particular de quase-experimento é o natural, caracterizado pela divisão entre dois grupos que se dá em função de uma qualquer intervenção exógena. O mecanismo de atribuição dos casos aos grupos está fora do controle do pesquisador na medida em que a intervenção externa configura o tratamento. No experimento natural, o pesquisador atribui os casos aos grupos com base nas diferenças naturais encontradas entre os grupos. Tais diferenças naturais podem ser limites políticos e jurisdicionais que separam dois grupos que detêm características similares ou, também, regras institucionais que estabelecem, por exemplo, quais grupos são beneficiados por um determinado tipo de programa do governo ${ }^{5}$. Esse último tipo é aquele ao qual nos referimos neste artigo. A regra institucional em questão é a presença nas Constituições estaduais da possibilidade de edição de MP por parte do governador. Ou seja, os seis casos antes mencionados, nos quais o governador faz uso da MP, são nosso grupo de tratamento selecionado em virtude da regulamentação formal dada ao instituto da MP. Nosso principal propósito é oferecer uma explicação para o argumento de que a MP no âmbito estadual não tem o mesmo efeito do que observamos para o uso que lhe atribuímos quando adotada pelo presidente da república. Em outras palavras, para responder à pergunta central relativa à ausência da MP como mecanismo legislativo privilegiado dos governadores nos estados, buscamos entender o que aconteceria caso a MP fosse introduzida na institucionalidade estadual. Observando o efeito real da MP nos seis

\footnotetext{
${ }^{4}$ Para uma revisão sobre a metodologia quase-experimento e uma reflexão sobre sua aplicação na ciência política, ver Gerber e Green (2008) e, sobretudo, Dunning (2008).

${ }^{5}$ Um exemplo conhecido na literatura de limites políticos e jurisdicionais é aquele oferecido por Posner que compara o comportamento político de dois grupos étnicos em dois países africanos (PosNER, 2004). No caso, o fato de os dois grupos étnicos serem politicamente aliados em um país e adversários em outro é explicado em função do tamanho dos grupos que difere entre os países. Um bom exemplo de regra institucional é encontrado em Ansolabehere et al (2000). Nesse estudo, os autores indagam como o redesenho do distrito eleitoral nos Estados Unidos que ocorre a cada dez anos influencia o comportamento dos políticos que buscam a reeleição. A redefinição dos limites geográficos do distrito permite aos autores comparar entre o peso eleitoral vindo de eleitores "novos" e dos "antigos", de modo a estimar a magnitude do voto pessoal. Outros exemplos de estudos de experimentos naturais podem ser encontrados em Dunning, 2008.
} 
OPINIÃO PÚBLICA, Campinas, vol. 18, no 2, novembro, 2012, p. 255-277

estados mencionados (o grupo tratamento) e comparando com os casos de estados que não adotaram a MP (o grupo controle) teremos uma resposta sobre o papel que este instrumento legislativo possui no âmbito subnacional.

O artigo está organizado da seguinte forma: começamos com um detalhamento dos seis casos que preveem o uso da MP pelo governador, descrevendo o processo formal de tramitação nas respectivas Assembleias estaduais e os motivos que levaram os legisladores daqueles estados a prever o uso da MP. Em seguida, tratamos do argumento principal do artigo, qual seja, que as MPs estaduais não conferem ao governador ampla preponderância legislativa em virtude da limitada autonomia no escopo legislativo dos estados. Analisando os dispositivos constitucionais da Carta de 1988, mostramos que os governadores têm limitada capacidade de formulação de uma agenda decisória própria, de modo que a MP estadual não poderia ser vista como medida unilateral que aumenta a capacidade de o executivo influenciar os resultados legislativos. Em seguida, analisamos o volume e o conteúdo das MPs emitidas nos seis estados sob investigação, comparando, quando possível, com a produção legal dos estados que não possuem a MP. A comparação entre as legislaturas estaduais nesses seis estados fornece a base empírica para a explanação das relações entre executivo e legislativo estadual brasileiro em um contexto institucional que atribui poderes extraordinários aos governadores. Para compreender melhor a dinâmica do uso das MPs no plano subnacional, aprofundamos a análise sobre a utilização de MPs no processo legislativo estadual catarinense entre 1989 e 2009. Na última seção, apresentamos as considerações finais em torno da escassa importância que as MPs possuem no contexto subnacional.

\section{Medidas Provisórias, governismo e experiência estadual}

No Brasil, seis dos 26 estados (Santa Catarina; Acre; Tocantins; Maranhão; Paraíba e Piauí) atribuem ao executivo estadual a prerrogativa de editar Medidas Provisórias (MPs). Em 1989, quatro estados (Acre; Piauí; Santa Catarina e Tocantins) reproduziram em suas Constituições Estaduais essa delegação legislativa para os seus Governadores ${ }^{6}$. Em 1994, também a Paraíba introduziu essa delegação em sua Constituição e, por último, o Maranhão adotou esse instrumento normativo em $2003^{7}$. Mais recentemente, houve outras duas tentativas de inclusão desse instrumento legislativo no Rio de Janeiro e Amazonas. Ambas, porém, não foram bem sucedidas ${ }^{8}$. Portanto, temos hoje seis estados em que os respectivos governadores dispõem da prerrogativa de edição de medidas provisórias.

A competência dos estados para instituir o estatuto da MP foi objeto de várias Ações Diretas de Inconstitucionalidade (ADI) junto ao Supremo Tribunal Federal (STF). Somente em 2002, depois de

\footnotetext{
${ }^{6}$ Vale lembrar que também alguns municípios instituíram em suas Leis Orgânicas o poder de decreto. O número exato de municípios em que os prefeitos possuem a capacidade de editar MP é incerto, mas alguns exemplos são Palmas (TO), João Pessoa (PB), São Leopoldo (RS), Rio Branco (AC) e Itapema (SC).

${ }^{7} \mathrm{Na}$ Paraíba, a instituição da MP no processo legislativo estadual foi dado pela EC 6, de 21 de dezembro de 1994, de autoria do deputado estadual Carlos Dunga (PMDB) e mais de um terço dos parlamentares paraibanos, conforme a exigência constitucional para a proposição de EC no estado. No Maranhão, a MP resultou da EC 38, de 30 de janeiro de 2003, proposta pelo governador do estado.

${ }^{8}$ No primeiro caso, a PEC 18/2003, de autoria do deputado estadual Armando José, foi arquivada pela Comissão de Constituição e Justiça com um parecer de inadmissibilidade. No Amazonas, uma PEC de junho de 2007, de autoria do deputado estadual Ricardo Nicolau (PRONA), vice-líder do governo, propôs a introdução da MP no processo legislativo estadual. Além de ser arquivada, a maioria dos legisladores estaduais rejeitaram essa PEC e aprovaram e promulgaram a EC 61 (PEC 7/2007), de 11 de julho de 2007, de autoria do deputado Sebastião Reis (PR), suprimindo o Inciso IV do Art. 31 da Constituição estadual e retirando do executivo a prerrogativa de propor Leis Delegadas.
} 
RICCI, P.; TOMIO, F. O poder da caneta: a Medida Provisória no processo...

centenas de MP editadas pelos estados, essa prerrogativa foi julgada pelo Tribunal Pleno do STF, que assentou a constitucionalidade da adoção da MP pelos estados. No caso, o Tribunal Pleno do STF decidiu a ADI 425, ajuizada pelo Partido do Movimento Democrático Brasileiro (PMDB) do Tocantins, contra o então governador de Tocantins, Siqueira Campos, e a Assembleia Legislativa do estado. No julgamento dessa ADI, que teve como relator o Ministro Maurício Corrêa, o pleno do STF, por maioria (com único voto vencido do Ministro Carlos Velloso), assentou a constitucionalidade da adoção da MP pelos estados em face do princípio da simetria constitucional, fixado no art. 25 da Constituição Federal, segundo o qual "os Estados organizam-se e regem-se pelas Constituições e leis que adotarem, observando os princípios desta Constituição". Ou seja, os governadores podem adotar MPs desde que haja disposição em tal sentido na Constituição de seu estado e que as mesmas sejam sucessivamente convertidas em leis pelos legislativos estaduais.

É fundamental, então, tratar do processo de regulamentação das MPs estaduais. A análise é feita a partir da leitura das constituições estaduais e do regimento interno de cada Assembleia Legislativa que marcam o formato legal da tramitação das MPs estaduais. É possível definir, pelo menos, cinco características relevantes na delegação de MP entre os estados. A Tabela 1 as sintetiza:

Tabela 1

Regulamentação das Medidas Provisórias (MP) Estaduais

\begin{tabular}{|c|c|c|c|c|c|c|}
\hline Características & Acre & Maranhão & Paraíba & Piauí & Santa Catarina & Tocantins \\
\hline $\begin{array}{l}\text { Motivo para Edição } \\
\text { de MP }\end{array}$ & Ausente & $\begin{array}{l}\text { Relevância e } \\
\text { Urgência }\end{array}$ & $\begin{array}{c}\text { Relevância e } \\
\text { Urgência }\end{array}$ & $\begin{array}{l}\text { Calamidade } \\
\text { Pública }\end{array}$ & $\begin{array}{c}\text { Relevância e } \\
\text { Urgência }\end{array}$ & $\begin{array}{l}\text { Relevância e } \\
\text { Urgência }\end{array}$ \\
\hline $\begin{array}{l}\text { Tempo de Vigência da } \\
\text { MP }\end{array}$ & Ausente & $60 / 60$ dias & 30 dias & 30 dias & $\begin{array}{c}30 \text { dias e } \\
60 / 60 \text { dias de } \\
17 / 07 / 09 \text { (EC } \\
49)\end{array}$ & 30 dias \\
\hline $\begin{array}{l}\text { Terminado o prazo ou } \\
\text { rejeitada a MP, forma } \\
\text { de normatização dos } \\
\text { efeitos da MP }\end{array}$ & Ausente & $\begin{array}{l}\text { Decreto } \\
\text { Legislativo }\end{array}$ & $\begin{array}{l}\text { Decreto } \\
\text { Legislativo }\end{array}$ & Ausente & $\begin{array}{l}\text { Decreto } \\
\text { Legislativo }\end{array}$ & $\begin{array}{l}\text { Decreto } \\
\text { Legislativo }\end{array}$ \\
\hline $\begin{array}{l}\text { Vedações à Reedição } \\
\text { MP, na mesma } \\
\text { sessão legislativa, } \\
\text { não deliberada ou } \\
\text { rejeitada }\end{array}$ & Ausente & SIM & Ausente & Ausente & SIM & Ausente \\
\hline $\begin{array}{l}\text { Vedações à Edição de } \\
\text { MP, sobre matéria } \\
\text { reservada a LC ou a } \\
\text { PPA/LDO/Orçamento }\end{array}$ & Ausente & SIM & Ausente & Ausente & SIM & Ausente \\
\hline
\end{tabular}

Fonte: Constituições Estaduais e Regimentos Internos das Assembleias Legislativas

Em primeiro lugar, o motivo constitucional para o executivo editar o decreto. Há três situações possíveis, que variam de total, restrita ou irrelevante discricionariedade do executivo, dentre os seis estados. A ausência de prescrição caracteriza a MP no Acre, que permite a total discricionariedade do executivo na edição de MP. Os casos de Maranhão, Paraíba, Santa Catarina e Tocantins retomam o motivo da decretação presente na Constituição Federal, isto é, a relevância e urgência, muito similar ao caso anterior, mas passível de julgamento dos legisladores sobre o acolhimento da MP (uma cláusula de segurança contra abusos na utilização da delegação). A calamidade pública torna a delegação de MP 
OPINIÃO PÚBLICA, Campinas, vol. 18, n² 2, novembro, 2012, p. 255-277

irrelevante, dado que, quando há a declaração de calamidade pública, o executivo já possui poderes excepcionais em sua atuação política. Esse é o caso do Piauí.

Um segundo aspecto a ser considerado é o tempo de vigência da MP sem a manifestação dos parlamentares estaduais. Isoladamente, quanto maior o tempo de vigência, maior seria o grau de delegação. No limite, nenhuma previsão de perda de vigência, como no Acre, indicaria uma extrema delegação, só superada pelo Decreto-Lei do regime militar. Contudo, vedações complementares (como o impedimento de reedições de MP) seriam mais eficazes à restrição da edição de MP, diante de prazos curtos de vigência. Com a exceção do Acre, todos os tempos de vigência seguem as diretrizes prescritas e vigentes para a edição de MP pelo executivo federal, independentemente da forma de sua introdução no processo estadual: 30 dias nos estados de Tocantins, Piauí, Santa Catarina (em 1989) e Paraíba (em 1994); 60 dias com prorrogação de mais 60 dias no Maranhão (em 2004) e Santa Catarina (em 2009), todas decisões posteriores à alteração da delegação na Constituição Federal pela EC 32/2001.

Um terceiro aspecto a tratar é o instrumento utilizado para normatizar os efeitos de uma MP rejeitada ou com perda de vigência. Esse indicador expressa a capacidade de a Assembleia normatizar autonomamente (sem a sanção do governador) os efeitos de uma MP rejeitada. Se a normatização é feita por Decreto Legislativo, como no caso Federal e dos estados do Maranhão, Paraíba, Santa Catarina e Tocantins, menor é o grau de delegação. Caso não haja previsão, como no Acre e Piauí, somente uma nova MP ou um PL aprovado normatizariam os efeitos, indicando maior grau de delegação.

Por fim, as vedações à edição de MP são instrumentos explícitos de restrições na delegação. Quanto mais restrita a edição de MP, menor a delegação legislativa. As restrições mais importantes são: a) às reedições de MP na mesma legislatura e b) ao escopo normativo da MP (vedações à edição de MP sobre matéria reservada à Lei Complementar ou ao PPA/LDO/Orçamento). Nos dois casos, só há referência constitucional dessas restrições nos estados do Maranhão e de Santa Catarina, que as instituíram por Emenda constitucional seguindo as diretrizes da Emenda Constitucional federal 32/2001, que regulamentou o uso da medida provisória pelo Presidente da República, estabelecendo limites à reedição e uma tramitação mais rigorosa.

Em geral, pode-se dizer que há uma razoável variação nas regras de edição e do processo decisório da MP nos estados. O que importa sublinhar, aqui, é que a institucionalização da MP pelos parlamentares estaduais tende, em sua maioria, a remeter diretamente ao formato legal previsto no âmbito federal. Vale lembrar que a edição de MP foi prevista, exclusivamente, como delegação legislativa ao executivo federal na Constituição de 1988. Neste caso, deu-se continuidade à experiência constitucional anterior, na qual, de acordo com a Constituição de 1967, o governo podia utilizar do decreto-lei. Porém, ao contrário do previsto em 1967, na Constituição de 1988, não houve vedação explícita à adoção desse instrumento normativo pelos estados ${ }^{9}$. Nesse sentido, o processo de institucionalização do poder de decreto estadual sugere que, de certa forma, a Constituição de 1988 , enquanto guia à construção das constituições estaduais, poderia ter orientado os legisladores estaduais

\footnotetext{
${ }^{9}$ O Art. 188 da Constituição promulgada em 1967, adotada em pleno regime militar, determinava o prazo de sessenta dias para os estados adaptarem suas Constituições à reforma promovida naquele ano e, em seu parágrafo único, estabelecia que "as Constituições dos estados poderão adotar o regime de leis delegadas, proibidos os decretos-leis".
} 
RICCI, P.; TOMIO, F. O poder da caneta: a Medida Provisória no processo...

que, antecipando possíveis dificuldades para os governadores na execução de determinadas políticas ou simplesmente replicando o processo legislativo a seus estados, adaptaram a MP ao processo decisório estadual.

Essa constatação é de extrema importância. A partir dela é plausível pensar que as decisões coletivas tomadas nas constituintes estaduais poderiam replicar a lógica que dominou o formato da MP federal. No caso, uma das teses majoritariamente defendidas pelos constituintes de 1988 em defesa da adoção da MP era a necessidade de introduzir um instrumento legal para responder de forma rápida às pressões vindas da sociedade (FIGUEIREDO e LIMONGI, 1999) ${ }^{10}$. A introdução do legado institucional federativo, portanto, é certamente válido como forma para explicar o processo de regulamentação das MPs nos estados ${ }^{11}$. Entretanto, sozinho, não explica a delegação legislativa da MP no âmbito subnacional. O legado político, talvez, torna-se plausível para os casos em que a MP foi introduzida inicialmente, como no Acre, Piauí, Santa Catarina e Tocantins. Mas, fica a pergunta: como explicar a ausência de um mesmo instrumento de delegação nos demais estados? Evidentemente, precisamos de outra resposta, capaz de interpretar, ao mesmo tempo, presença e ausência da MP nos estados brasileiros. Na próxima seção, defendemos o argumento de que as MPs estaduais não ampliam o poder de agenda dos governadores, dado que as prerrogativas normativas dos estados estão amplamente definidas na Constituição Federal. Desse modo, a MP estadual acrescenta ao governador um instrumento legislativo privilegiado sobre questões restritas, não sendo, de fato, um instrumento capaz de aumentar a capacidade de o governador influenciar significativamente o seu sucesso legislativo. Isso explicaria sua adoção em poucos estados. Na sequência, mostramos evidências em tal sentido.

\section{O instituto da Medida Provisória nos estados: hipóteses e evidências para explicar seu uso limitado}

Para que o significado da adoção da MP no plano estadual seja esclarecido, consideramos em primeiro lugar as ponderações feitas para a existência da MP no âmbito federal. Aqui, dois argumentos costumam ser apresentados $^{12}$. O primeiro deles interpreta a introdução da delegação de poder de decreto no processo decisório para dotar o governo de autoridade para responder rapidamente e com agilidade às exigências complexas da gestão pública, garantindo maior eficácia e qualidade às ações do governo (AMORIM e TAFNER, 2002). Interessante notar que na literatura internacional tal argumento enquadra-se na lógica do que vem habitualmente chamado de parlamentarismo racionalizado. A noção de racionalização vem associada à de centralização decisória dentro do parlamento, passando-se a reconhecer um peso relevante apenas a alguns parlamentares, como as lideranças, enquanto são fortalecidas as funções do executivo no processo legislativo. Esse processo acompanha a história da

\footnotetext{
10 Para uma reconstrução das ideias e das posições dos partidos durante a Constituinte, ver Figueiredo e Limongi (1999).

11 De acordo com Orloff (1993), o legado político existente interfere no debate político e na formação de interesses/coalizões políticas. Mais do que a ideologia e os interesses sociais, esse policy feedback institucional determinaria a inovação políticoinstitucional, motivando e moldando as iniciativas políticas dos atores sociais e políticos-estatais e determinado a construção de coalizões políticas nesse processo decisório.

12 Para uma melhor compreensão da prática do uso do decreto-lei em outras experiências democráticas, ver o texto de Carey e Shugart (1995, 1998).
} 
OPINIÃO PÚBLICA, Campinas, vol. 18, no 2, novembro, 2012, p. 255-277

evolução dos parlamentos da Europa desde pelo menos o século XIX13. No Brasil, porém, até meados dos anos noventa, a imagem de um fortalecimento do executivo não derivava do reconhecimento da presença de um parlamento racionalizado, mas, pelo contrário, originava-se da constatação de sua fraqueza política. Em um contexto legislativo altamente fragmentado, em presença de partidos geralmente indisciplinados e de deputados interessados na busca por benefícios locais, o exercício do "bom governo" seria uma operação árdua para o presidente (AMES, 2001; LAMOUNIER, 1994; MAINWARING, 1999). A medida provisória, portanto, do ponto de vista do legislador, serviria como instrumento legislativo forte para evitar futuros obstáculos para a governabilidade.

Um segundo argumento, derivado da literatura americana, tende a defender a imagem da delegação parlamentar da medida provisória como produto da institucionalização da transferência ao executivo de decisões políticas de alto custo quando avaliadas na perspectiva da reeleição. Conforme esta hipótese, haveria uma divisão de trabalho entre executivo e legislativo. O legislador transferiria para - executivo a tomada de decisões políticas em áreas delicadas para suas perspectivas eleitorais, omitindo-se do ônus advindo na proposição de determinadas políticas. A delegação de algumas áreas transferiria os custos de decisão ao executivo e diminuiria os custos eleitorais do legislativo. Esse argumento origina-se da leitura que os autores fazem dos incentivos eleitorais. No caso, os deputados, interessados na reeleição, buscam com o cargo promover políticas públicas que satisfaçam bens locais, geograficamente concentrados (CAIN et al, 1987). O presidente, por sua vez, dada a natureza de sua eleição, representante da nação inteira, tenderia a se preocupar mais com questões de abrangência nacional (SHUGART e HAGGARD, 2001). Assim, as decisões custosas, ou que remetem à provisão de bens coletivos, são internalizadas, no Congresso, pelas lideranças políticas e, no executivo, pelo presidente (Cox e McCubbins, 2001).

Essas formas de argumentar têm levantado um amplo debate na literatura assim como entre políticos e juristas. O tema do abuso e da banalização desse instrumento pelo executivo tem caracterizado a maioria das análises (PeSSANHA, 1997; MAINWARING, 1999; SANTOS, 1997). De certa forma, o debate travou no imaginário de que a medida provisória possa constituir uma abdicação das funções legislativas próprias dos deputados ou, ao contrário, uma simples delegação de funções (Figueiredo e Limongl, 1999; Amorim Neto e TAfNer, 2002; Reich, 2002; Da Ros, 2008). O Ministro do STF, Carlos Velloso, por exemplo, no seu voto contrário dado ao reconhecimento da competência dos governadores em editar MPs, enfatizava os abusos que vinham sendo praticados no âmbito federal. A nosso entender, as diferentes interpretações acerca do uso da MP, assim como o debate travado entre os estudiosos e no próprio ambiente político, não devem ser introduzidas para o caso subnacional por uma razão bem simples: as MPs estaduais têm um caráter diferente das que são apresentadas pelo Presidente da República. Sustentamos a ideia de que as MPs estaduais sejam mais um instrumento legislativo acessório nas mãos dos governadores de alguns estados, sem que isso thes garanta poderes fortes e inequívocos que os diferencie dos demais governadores privados desse mecanismo legislativo. 13 Para um estudo do processo de racionalização ocorrida no Reino Unido, ver o estudo de Cox (1989). O caso francês, na
passagem entre quarta e quinta república, é aprofundado por Huber (1996). 
RICCI, P.; TOMIO, F. O poder da caneta: a Medida Provisória no processo...

Algumas considerações e alguns dados nos permitem reconhecer a validade dessa interpretação, descartando assim a ideia de que a MP estadual seja fruto da necessidade de garantir a governabilidade e/ou de uma delegação de funções e competências por parte do legislador. Em primeiro lugar, basta lembrar o número reduzido de estados que constitucionalizaram a MP desde 1988. Se o argumento da resposta rápida aos problemas da máquina administrativa fosse válido, deveríamos esperar uma inclusão nas constituições estaduais do mecanismo do poder de decreto bem mais frequente. Agora, não apenas isso não se verifica, mas as tentativas de introduzi-lo após a ratificação das constituições estaduais limitam-se aos casos da Paraíba (em 1994), do Maranhão (em 2003), do Rio de Janeiro e do Amazonas. Nesses dois últimos casos, porém, a tentativa não foi bem sucedida. Além disso, na Paraíba, a primeira medida provisória editada foi em 2003, isto é, nove anos depois da inclusão desse instrumento jurídico na Constituição. Ou seja, a suposição de que o executivo participou no processo constituinte estadual para garantir a si mais poderes estaria limitada apenas aos casos em que a MP foi introduzida na Constituição estadual em 1989.

Entretanto, um segundo argumento, desenvolvido a partir da contribuição recente de Ricci e Tomio (2012), frustra esta suposição. Basta darmos uma olhada para a distribuição das competências entre União e estados assim como foram definidas pela Carta Constitucional de 1988. Deve-se observar que, no que tange ao sistema de distribuição de competências, em princípio, todas as competências (legislativas, administrativas e judiciárias) podem ser distribuídas entre o governo federal e os governos estaduais. As competências judiciárias podem até ser centralizadas pelo nível federal sem grandes prejuízos ao pacto federativo. Contudo, não há dúvida que a atribuição das demais competências aos governos estaduais é indispensável para um sistema federal (GAMPER, 2005). A Constituição federal define (em seu Art. $25, \S 1^{\circ}$ ) que "são reservados aos Estados as competências que não Ihes sejam vedadas por esta Constituição". Como a Constituição de 1988 é extremamente detalhada nas atribuições da União, dos Estados e dos Municípios, compete estritamente aos estados legislar de forma "concorrente" com a União. A Tabela 2 esquematiza as competências legislativas privativas e concorrentes da União e dos estados (e entre executivo e legislativo): 
OPINIÃO PÚBLICA, Campinas, vol. 18, no 2, novembro, 2012, p. 255-277

Tabela 2

Distribuição de Poderes Legislativos (entre União e Estados, Executivo e Legislativo)

Constituição Federal de 1988

\begin{tabular}{|c|c|c|c|}
\hline \multicolumn{4}{|c|}{ Poderes Legislativos (Executivo e Legislativo) } \\
\hline & Privativa Executivo & Concorrente & $\begin{array}{c}\text { Privativa } \\
\text { Legislativo }\end{array}$ \\
\hline Privativo da União & . & $\begin{array}{c}\text { Fundamentais; Nacionalidade; } \\
\text { Organização dos poderes; } \\
\text { Organização do estado; Político; } \\
\text { Eleitoral; Civil; Penal; Processual; } \\
\text { Defesa; Segurança; Financeiro; } \\
\text { Agrário; Comercial; Comunicações; } \\
\text { Riquezas minerais/atômicas; } \\
\text { Marítimo; Aeronáutico/espacial; } \\
\text { Trabalho; Trânsito; Transportes } \\
\end{array}$ & - \\
\hline $\begin{array}{l}\text { Concorrente } \text { - norma geral } \\
\text { (Federal) e específica } \\
\text { (Estadual) }\end{array}$ & . & $\begin{array}{l}\text { Social; Política urbana; Econômico; } \\
\text { Ambiental; Patrimônio histórico }\end{array}$ & . \\
\hline $\begin{array}{c}\text { Concorrente - Paralela } \\
\text { (plenas e não excludentes) } \\
\text { entre União e Estados }\end{array}$ & $\begin{array}{l}\text { Orçamentário; } \\
\text { Administrativo }\end{array}$ & Tributário; Organização (território) & - \\
\hline Privativa dos Estados & . & . & . \\
\hline
\end{tabular}

É mais do que evidente que o escopo decisório do legislativo estadual sofre de grande limitação na produção legislativa. Como se vê, o legislador estadual propõe, concorrentemente com a União, em assuntos tributários, econômicos, de políticas públicas (educação, saúde, desenvolvimento, meio. ambiente, etc.) e administração pública - geralmente, a partir de critérios claramente expressos na Constituição e nas Leis Complementares federais. Além disso, a mesma constituição elevou os municípios ao status de entes federativos, reservando a esses o home rule e a plena autonomia política ${ }^{14}$. Portanto, toda esfera de "assuntos de interesse local" tornou-se objeto normativo de decisões legislativas dos governos municipais. Para além do mais, deve-se constatar que a competência exclusiva do executivo estadual é restrita a poucos temas. Na prática, como a União possui competência normativa exclusiva abrangente (vinte e nove temas, que vão do direito civil e penal à propaganda comercial e ao serviço postal), resta aos estados o papel de produzir norma jurídica muito limitada ${ }^{15}$ (RICCI e Tomıo, 2012).

O que acabamos de dizer contrapõe-se à literatura dos anos noventa (em particular ver Stepan, 1999), que considerava o Brasil um dos mais descentralizados países na América Latina, e confirma os achados de outros autores que, recentemente, defendem a ideia de um federalismo brasileiro onde há um forte controle exercido pela União sobre as instâncias inferiores (ARRETCHE, 2007; 2009; SouZA, 2005; Tомıо et al, 2010). Assim, por exemplo, Arretche, ao analisar o processo de mudança que ocorreu

14 Ver Tomio (2005a, 2005b, 2005c).

15 O Art. 24. da Constituição Federal de 1988 determina que "Compete à União, aos Estados e ao Distrito Federal legislar concorrentemente sobre: (...) $\S 1^{\circ}$. No âmbito da legislação concorrente, a competência da União limitar-se-á a estabelecer normas gerais. $\S 2^{\circ}$. A competência da União para legislar sobre normas gerais não exclui a competência suplementar dos Estados. $\S 3^{\circ}$. Inexistindo lei federal sobre normas gerais, os Estados exercerão a competência legislativa plena, para atender a suas peculiaridades. $\S 4^{\circ}$. A superveniência de lei federal sobre normas gerais suspende a eficácia da lei estadual, no que Ihe for contrário". 
RICCI, P.; TOMIO, F. O poder da caneta: a Medida Provisória no processo...

nos anos noventa, aponta que os formuladores da Constituição Federal de 1988 "criaram um modelo de Estado federativo que combina ampla autoridade jurisdicional à União com limitadas oportunidades institucionais de veto aos governos subnacionais" (ARRETCHE, 2009, p. 380). Portanto, a própria MP estadual sofre das limitações impostas pelo arcabouço federativo. Eis o ponto central do nosso argumento: a institucionalização da MP não atribui aos governadores um papel preponderante no processo legislativo estadual. Mais precisamente, a presença de MP como instrumento legal estadual não amplia significativamente os poderes legislativos do executivo estadual. Isso significa dizer que, com ou sem o poder de decreto estadual, os governadores controlariam a já limitada agenda decisória nos estados, mensurada em sua capacidade de impacto normativo decorrente da legislação estadual e não da autonomia executiva dos estados. A nosso entender, isso explica a presença do instituto da MP em apenas alguns estados. Isto não significa dizer que a ocorrência de MP seja inócua no processo decisório, mas, que a MP estadual somente acrescentaria um instrumento legislativo privilegiado sobre questões muito restritas da administração pública estadual ${ }^{16}$. Portanto, seria esperado tanto um menor uso desta prerrogativa quanto uma menor relevância institucional de seus efeitos jurídicos e políticos nos estados, quando comparados aos efeitos na esfera federal. Desta forma, não seria possível reproduzir integralmente as hipóteses sobre as relações executivo/legislativo do plano federal para o plano estadual.

Isso abre espaço para oferecer algumas evidências mais consistentes. Se o argumento que acabamos de expor for válido, devemos encontrar um uso esporádico e apolítico das MPs naqueles estados que preveem esse recurso. Dito de outra forma, significa que o padrão identificado nos estados é de um uso da MP que não interfere no sucesso legislativo do governador. Em primeiro lugar, observa-se a utilização que o governador fez das MPs ao longo do tempo. Sabemos que no Congresso Nacional o executivo faz amplo uso desse instrumento legislativo (FIGUEIREDO e LIMONGI, 1999; LIMONGI, 2006). Seria o mesmo para os estados que introduziram em suas constituições as MPs? Para responder a esta pergunta, analisamos, primeiramente, os valores relativos ao volume total da legislação aprovada, distinguindo entre MPs e o conjunto das propostas ordinárias de origem do executivo e do legislativo convertidas em lei (Tabela 3). Os dados são incontestáveis. O volume das leis por estados mostra que entre 1989 e 2009 foram editadas apenas 692 MPs pelos governadores de cinco dos seis estados com essa delegação legislativa. Não incluímos o estado do Piauí por uma simples razão: aqui, nenhuma MP foi proposta pelo executivo durante todo o período constitucional recente. Lembre-se que Piauí é o estado com as regras mais restritivas para edição já que considera a possibilidade da edição apenas em

\footnotetext{
16 Além da Medida Provisória (MP), outra forma de delegação legislativa atribuída ao executivo são as Leis Delegadas (LD). Somente seis estados não possuem esse instrumento legislativo previsto em suas Constituições Estaduais: São Paulo, Rio Grande do Sul, Espírito Santo, Piauí, Maranhão e Amazonas (sendo que este último retirou a prerrogativa da LD por Emenda Constitucional 61/2007). As informações disponíveis do processo legislativo estadual (Rıccl e Tomı, 2012) indicam que a maioria dos estados não faz uso frequente do dispositivo da LD. As exceções mais significativas são algumas legislaturas em Minas Gerais, Roraima, Alagoas e Amazonas (antes da EC 61/2007). Nenhum dos estados que possuem simultaneamente os dois mecanismos de delegação legislativa ao executivo utilizam a LD, assim como acontece com o nível federal, onde somente duas LDs foram editadas após a Constituição de 1988 (LD 12 e 13/1992). O motivo parece estar relacionado ao grau de delegação da LD, que é muito inferior à MP, dado que seu escopo normativo é mais restrito e cada delegação deve ser aprovada ad hoc pelo legislativo através de Resolução (que especifica o seu conteúdo, os termos de seu exercício e a necessidade de apreciação posterior). Logo, um governador que possa editar MP não teria incentivo para solicitar LD. Além disto, dada as prerrogativas normativas estaduais limitadas e o controle do executivo sobre esta, seria esperada uma relevância ainda menor para o instrumento da LD, comparado à MP, no processo legislativo estadual.
} 
OPINIÃO PÚBLICA, Campinas, vol. 18, no 2, novembro, 2012, p. 255-277

caso de calamidade pública. Certamente, a exigência de motivo de calamidade pública praticamente torna irrelevante esse dispositivo constitucional, dado que quando a calamidade pública é oficialmente declarada pelo governo estadual, esse ator já dispõe de medidas excepcionais para agir durante a crise, efetivadas, em geral, através de decretos do executivo. 
Tabela 3

Leis Ordinárias (LEI) e Medidas Provisórias (MP) nos Estados (1989-2009, por ano)

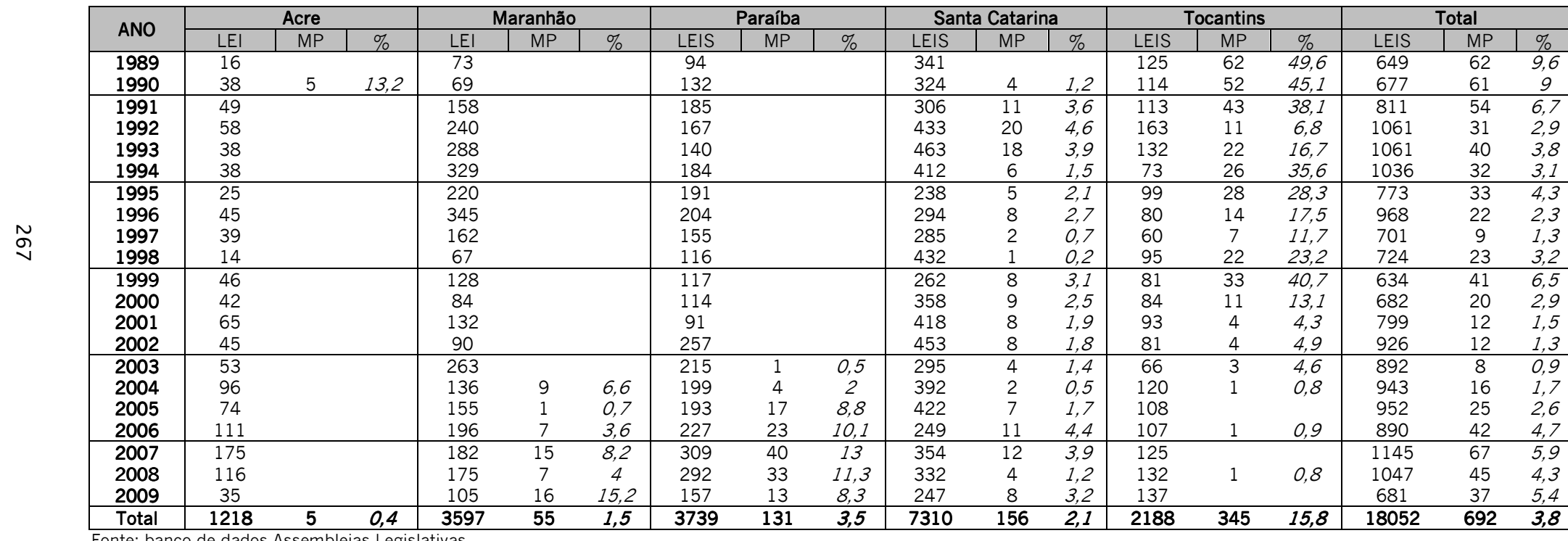


OPINIÃO PÚBLICA, Campinas, vol. 18, no 2, novembro, 2012, p. 255-277

Por outro lado, no Acre, somente cinco MPs foram editadas, todas em 1990. Todas elas versaram sobre matéria de iniciativa exclusiva do executivo - como criação, estruturação e competência das secretarias e demais órgãos da administração pública direta e indireta - e foram convertidas em $\mid e^{17}{ }^{17}$. Ou seja, a delegação foi um expediente utilizado no estado apenas para a estruturação da máquina administrativa no período inicial do período pós-constituinte. No Tocantins, o histórico de utilização da MP é declinante. Aqui, a MP predominava inicialmente no cenário legislativo estadual. Mesmo antes de promulgada a Constituição do estado, o governador Siqueira Campos editava MPs, que tiveram que ser regulamentadas pelas disposições transitórias da Constituição ${ }^{18}$. De fato, em Tocantins, a maior parte da legislação sobre a pública foi originada por MP, isto é, o estado foi instituído pela delegação legislativa. Já nas últimas duas legislaturas, a edição de MP ocorre em número extremamente restrito, inferior ao presente nos outros três estados. No Tocantins, é corroborada a hipótese de influência do governador na institucionalização da MP no estado. Provavelmente, sem essa delegação, o executivo também teria controlado a agenda decisória estadual, dado que sempre contou com apoio majoritário na Assembleia. Entretanto, com a MP, o executivo obteve celeridade no processo de institucionalizar a administrativa do estado, isolando totalmente a oposição partidária, que recorreu, sem sucesso, através de ADI pra sustar essa delegação. Na Paraíba, observamos que, enquanto a Emenda Constitucional que introduziu a MP nesse estado foi promulgada em 1994, a primeira edição de uma MP ocorreu somente nove anos depois, em 2003. Conforme os dados apresentados na Tabela 3, apenas em Santa Catarina observamos a menor oscilação na edição de MP em todos os anos, entre 1990 e 2009, nunca superando, porém, 5\% das leis aprovadas ao ano.

Os dados expostos mostram apenas que as MPs não são dominantes e que o governador não se serve delas para aprovar sua agenda. Entretanto, não podemos inferir de imediato que o executivo não se utilize desse instrumento legislativo para produzir normas. Do ponto de vista do desenho de pesquisa aqui proposto, isto é, o experimento natural, o teste deveria ser feito agora observando o efeito do uso da MP na comparação da produção legal para os estados que adotam a MP com os demais que não possuem este instrumento legal. Agindo dessa forma, teremos uma comparação das diferenças em termos de produção legal e do peso efetivo da MP. A melhor estratégia para verificar quanto o governador se utiliza desse recurso seria comparar a taxa de dominância sobre a produção legal para os estados que não adotam a MP com a dos estados que adotam a MP. Assim, observaríamos quanto o volume de MPs editadas incide sobre o total de leis aprovadas de origem do executivo. Isso nos daria a dimensão da "intensidade" com que o governador recorreu às MPs. De acordo com Ricci e Tomio

\footnotetext{
17 A MP 01/1990 (Lei 937/1990, "Dispõe sobre a reestruturação parcial do Sistema Estadual de Administração"); a MP 02/90 (Lei 950/1990, "Organiza a Administração Pública Estadual, reestrutura parcial o Poder Executivo"); a MP 03/1990 (Le 949/1990, "Dispõe sobre o desdobramento da Estrutura Básica da Assessoria de Comunicação Social"); a MP 04/1990 (Lei 947/1990, "Dispõe sobre o desdobramento da Estrutura Básica da Secretaria de Estado de Administração"); a MP 05/90 (Le 948/1990, "Dispõe sobre alteração na estrutura básica do Departamento de Estradas de Rodagem do Estado do Acre . DERACRE").

18 O Art. 4 e seu parágrafo único, das disposições transitórias de TO, especificam o tratamento das MP anteriores à promulgação da Constituição: "as medidas provisórias que tiverem sido editadas e publicadas até 5 de setembro de 1989 , serão apreciadas no prazo e sob as condições estipuladas no $\S 4^{\circ}$, do art. 27, desta Constituição. Parágrafo único. As medidas provisórias editadas a partir de 5 de setembro de 1989, até a data da promulgação desta Constituição, serão transformadas em projeto de lei, submetido à tramitação prevista no Regimento Interno da Assembleia Legislativa".
} 
RICCI, P.; TOMIO, F. O poder da caneta: a Medida Provisória no processo...

(2012), os executivos dos estados que não possuem a MP têm um índice de dominância legislativa igual a $26,4 \%$. Ou seja, de todas as leis sancionadas, menos de um terço foi apresentada pelo governador.

Infelizmente, as informações acerca da origem das propostas sancionadas para os casos que adotam a MP limitam-se a Santa Catarina e ao Acre ${ }^{19}$. Como visto, no Acre, apenas 5 MPs foram introduzidas em 1990. Mais significativo é o caso de Santa Catarina, já que conhecemos a série histórica das normas aprovadas desde 1989. Aqui, basta dizer que, entre 1990 e 2009, apenas 5,6\% das leis oriundas do executivo tinham sido apresentadas sob o formato de MPs.

Para encontrarmos evidências para os outros estados - Paraíba, Maranhão e Tocantins podemos recorrer a um estratagema. Consideramos a taxa de dominância do executivo encontrada por Ricci e Tomio (2012) para os estados que não usam a MP como valor de referência para estimar para os três estados sem informação o volume total de produção legislativa oriunda do executivo. Assumimos, portanto, que, em cada estado, $26,4 \% \%$ das leis sejam propostas pelo governador ${ }^{20}$. A partir desse dado, verificamos sucessivamente qual a proporção de MPs editadas. Uma alternativa foi considerar o caso de Santa Catarina. É o único estado em que conseguimos as informações sobre as leis sancionadas diferenciando por origem e que apresenta uma série histórica completa. No caso, 35,9\% das propostas ordinárias sancionadas entre 1989 e 2009 eram do executivo catarinense.

A Tabela 4 reporta os dados para Maranhão, Tocantins e Paraíba relativos ao volume das MPs, das leis ordinárias do executivo calculados usando, respectivamente, o valor médio de $26,4 \%$ de leis e o de $35,9 \%$ e, por fim, o percentual de MPs sobre o total de leis de iniciativa do executivo. Para efeito de síntese, apresentamos os dados apenas com os valores médios para o período.

Tabela 4

Quantidade de Leis Ordinárias e Medidas Provisórias (MP) oriundas do executivo nos Estados

\begin{tabular}{|c|c|c|c|c|c|c|}
\hline \multirow[t]{2}{*}{ Estados } & \multirow[t]{2}{*}{$\begin{array}{l}\text { Anos de } \\
\text { referência }\end{array}$} & \multirow[t]{2}{*}{$\begin{array}{l}\text { MPs } \\
(\mathrm{N})\end{array}$} & \multicolumn{2}{|c|}{$\begin{array}{c}\text { Estimativa de leis oriundas do } \\
\text { executivo fixada em } 26,4 \% \text { do total } \\
\text { de leis }\end{array}$} & \multicolumn{2}{|c|}{$\begin{array}{c}\text { Estimativa de leis oriundas do } \\
\text { executivo fixada em } 35,9 \% \text { do total } \\
\text { de leis }\end{array}$} \\
\hline & & & $\begin{array}{l}\text { Leis ordinárias } \\
\text { do executivo } \\
\text { (LEI_GOV) }\end{array}$ & $\begin{array}{l}\text { MP/(MP + } \\
\text { Lei_GOV) } \\
(\%)\end{array}$ & $\begin{array}{l}\text { Leis ordinárias } \\
\text { do executivo } \\
\text { (LEI_GOV) }\end{array}$ & $\begin{array}{c}\text { MP/(MP + } \\
\text { Lei_GOV) (\%) }\end{array}$ \\
\hline Maranhão & $\begin{array}{l}2004 \cdot \\
2009\end{array}$ & 55 & 950 & 5,5 & 1291 & 4,1 \\
\hline Paraíba & $\begin{array}{l}2003 . \\
2009\end{array}$ & 131 & 987 & 11,7 & 1342 & 8,9 \\
\hline Tocantins & $\begin{array}{l}1989 . \\
2009\end{array}$ & 345 & 578 & 37,4 & 786 & 30,5 \\
\hline
\end{tabular}

Fonte: Banco de dados Assembleias Legislativas e Ricci e Tomio (2012).

\footnotetext{
${ }^{19}$ Apesar das frequentes visitas às Assembleias Legislativas daqueles estados, as informações que tivemos acesso limitaram-se na maioria dos casos, às duas últimas legislaturas. $O$ acesso aos dados através dos sites das Assembleia continua precário na maioria dos casos, como mostrou recentemente o trabalho de Braga (2007).

$20 \mathrm{O}$ fato de que os autores consideram apenas duas legislaturas (1999-2006), poderia levantar a dúvida sobre sua utilização para um período maior, entre 1989 e 2009. Entretanto, como outros estudos mostraram (SANTOS, 2001; ABRUCIO, 1998), o próprio formato da produção legislativa era similar em legislaturas anteriores. Por essas razões, nos pareceu válida a estratégia de considerar o valor médio de $26,4 \%$ para calcular a produção oriunda do executivo nos três estados sem informação.
} 
OPINIÃO PÚBLICA, Campinas, vol. 18, no 2, novembro, 2012, p. 255-277

Observa-se que o único caso em que, efetivamente, se pode afirmar que o governador faz uso substantivo das MPs é Tocantins. Entretanto, como visto anteriormente, esse recurso é declinante ao longo do tempo e, sobretudo, seu valor total ficou abaixo de um terço da produção legal do próprio governador. Em termos gerais, portanto, e diferentemente do âmbito federal, é possível afirmar que a presença da MP não é a forma predominante de proposição de norma no processo legislativo estadual.

Uma investigação sobre a produção legal não pode se eximir de estudar o conteúdo das MPs. 0 exercício proposto não é apenas descritivo, mas visa qualificar a produção legislativa do governador quando recorre à medida provisória. Sobretudo, trata-se de definir o grau de abrangência normativa da MP para verificarmos o uso real que o governador faz dela. A Tabela 5 classifica o conteúdo das MPs de acordo com a área de abrangência.

\section{Tabela 5}

Medidas Provisórias (MP) apresentadas nos Estados por conteúdo (1989.2009)

\begin{tabular}{|c|c|c|c|c|c|c|}
\hline \multirow[b]{2}{*}{ Estados } & \multicolumn{6}{|c|}{ Conteúdo das Medidas Provisórias } \\
\hline & \begin{tabular}{|l} 
Administração, \\
Orçamentária, \\
Finanças, etc
\end{tabular} & $\begin{array}{l}\text { Política } \\
\text { Pública } \\
\text { (Educação, } \\
\text { Saúde, } \\
\text { Ambiente, } \\
\text { etc.) }\end{array}$ & \begin{tabular}{|c|} 
Utilidade \\
Pública, \\
Denominação, \\
Homenagem, \\
etc.
\end{tabular} & $\begin{array}{c}\text { Sem } \\
\text { Referência }\end{array}$ & Prorrogação & Total \\
\hline Acre & $\begin{array}{c}5 \\
(100)\end{array}$ & . & . & . & . & $\begin{array}{c}5 \\
(100)\end{array}$ \\
\hline Maranhão & $\begin{array}{c}42 \\
(76,4)\end{array}$ & $\begin{array}{c}5 \\
(9,1)\end{array}$ & . & $\begin{array}{c}8 \\
(14,5)\end{array}$ & . & $\begin{array}{c}55 \\
(100)\end{array}$ \\
\hline Paraíba & $\begin{array}{c}110 \\
(84,0)\end{array}$ & $\begin{array}{c}14 \\
(10,7)\end{array}$ & $\begin{array}{c}4 \\
(3,1) \\
\end{array}$ & & $\begin{array}{c}3 \\
(2,2)\end{array}$ & $\begin{array}{c}131 \\
(100) \\
\end{array}$ \\
\hline $\begin{array}{c}\text { Santa } \\
\text { Catarina }\end{array}$ & $\begin{array}{c}138 \\
(88,5)\end{array}$ & $\begin{array}{c}11 \\
(7,1)\end{array}$ & - & $\begin{array}{c}7 \\
(4,4)\end{array}$ & . & $\begin{array}{l}156 \\
(100)\end{array}$ \\
\hline Tocantins & $\begin{array}{c}319 \\
(92,5)\end{array}$ & $\begin{array}{c}10 \\
(2,9)\end{array}$ & $\begin{array}{c}13 \\
(3,8)\end{array}$ & $\begin{array}{c}3 \\
(0,8)\end{array}$ & . & $\begin{array}{r}345 \\
(100)\end{array}$ \\
\hline Total & $\begin{array}{c}614 \\
(88,7)\end{array}$ & $\begin{array}{c}40 \\
(5,8)\end{array}$ & $\begin{array}{c}17 \\
(2,5)\end{array}$ & $\begin{array}{c}18 \\
(2,6)\end{array}$ & $\begin{array}{c}3 \\
(0,4)\end{array}$ & $\begin{array}{c}692 \\
(100)\end{array}$ \\
\hline
\end{tabular}

Fonte: Banco de dados Assembleias Legislativas.

Os dados são claros. Aproximadamente 90\% das MPs possuem efeito normativo sobre o mesmo tipo de legislação, isto é, leis direcionadas a regulamentar a administração pública como pessoal, orçamento, finanças, aspectos fiscais e patrimoniais. Os casos remanescentes, menos de $10 \%$, regulamentam a execução administrativa ou normatizam marginalmente outras políticas públicas nos estados, já extensamente reguladas pela Constituição e legislação federal como a educação, saúde, transportes, meio-ambiente, etc. ${ }^{21}$. Interessante a comparação com a produção legislativa ordinária das

\footnotetext{
21 Exemplos de regulação administrativa da execução e de normatização marginal de políticas: MP 53/1993 (SC) “Institui o programa de apoio a fiscalização e inspeção sanitária"; MP 90/2000 (SC) "Cria o conselho estadual de alimentação escolar e adota outras providências"; MP 85/2000 (SC) "Dispõe sobre os serviços de travessia de Ferry-Boat e balsa no rio Itajaí-Açu"; MP 12/2006 (MA) "Cria o Cadastro de Atividade Florestal, composto pelo Cadastro de Exploradores e Consumidores de Produtos Florestais do Estado do Maranhão -CEPROF-MA e pelo Sistema de Comercialização e Transporte de Produtos Florestais . SISFLORAMA, e dá outras providências"; MP 19/2007 (MA) "Dispõe sobre a criação do Conselho de Acompanhamento, Controle Social, Comprovação e Fiscalização do FUNDEB e dá outras providências"; MP 17/2005 (PB) "Autoriza empresa a se instalar nos distritos industriais da Paraíba e dá outras providências"; MP 63/2007 (PB) "Dispõe sobre a aplicação, no âmbito do estado da 
RICCI, P.; TOMIO, F. O poder da caneta: a Medida Provisória no processo...

Assembleias estaduais que não adotam a MP. De acordo com Ricci e Tomio (2012), o conteúdo da legislação do executivo tem valores elevados de leis direcionadas a regulamentar a administração pública como pessoal, orçamento, finanças, aspectos fiscais e patrimoniais, mas com valores inferiores aos registrados para os seis estados que adotam a MP. Ou seja, por mais que seja usada, a MP serve para produzir apenas um tipo peculiar de norma. É a partir dessa constatação que a lógica da presença das MPs no âmbito estadual deve ser esclarecida. Por último, decidimos apresentar o caso de Santa Catarina. As razões de sua escolha são claras: dos seis estados que agregaram a MP a suas Constituições, somente Santa Catarina faz uso contínuo desta forma para iniciar legislação estadual. Nessas condições, podemos observar como os governadores se serviram da MP ao longo do tempo 22 . A pergunta que surge é a seguinte: seria Santa Catarina um caso desviante, isto é, o único exemplo onde as MPs estaduais são usadas nos moldes das MPs em âmbito federal?

\section{Poder de decreto, decisões legislativas e relações executivo-legislativo em Santa Catarina}

Em Santa Catarina, o instituto da Medida Provisória foi introduzido na Constituição estadual de 1989. O Regimento Interno é mais claro e explícito sobre a tramitação das MP e seu processo legislativo também é mais complexo, com mais possibilidades de veto pelos atores políticos. A MP vai à Comissão de Constituição de Justiça para análise de admissibilidade cujo parecer vai ao plenário. Se a MP for rejeitada, elabora-se o PDL (Projeto de Decreto Legislativo) sobre sua insubstância. Se aprovado, retorna à CCJ para avaliação de Constitucionalidade e recebimento de emendas por cinco dias. 0 relator pode rejeitar as emendas. Sendo constitucional, vai às Comissões de Mérito por três dias, para emendas e parecer. Se inconstitucional, vai direto ao plenário para elaboração de PDL. Passadas 48 horas, o Presidente da Assembleia Legislativa indica relator para emitir parecer oral. Aprovada em plenário, converte-se em lei ordinária que vai à sanção do Governador. Caso a MP seja rejeitada pelo plenário, cabe a CCJ elaborar o PDL ${ }^{23}$.

De acordo com os dados expostos na Tabela 6, entre 1990 e $2009^{24}$, foram editadas em Santa Catarina 156 MPs. Quanto à iniciativa ordinária apresentada pelo executivo, entre 1995 e 2008, temos 1846 propostas (Projetos de Lei). Se compararmos o perfil da produção legislativa para o mesmo período, notamos que as MPs não adquirem saliência significativa. Ou seja, em quinze anos de trabalhos legislativos, os governadores serviram-se desse instrumento legislativo de forma residual. Importante notar que entre 1990 e 2009, quase um quarto (e mais de 1/3, em duas legislaturas, entre 1995 e 2002) das MPs não foram aprovadas pelo legislativo estadual, por não terem caráter emergencial, ferirem a Constituição ou não serem aprovadas em seu mérito pelos legisladores. Isto diante de governadores com

Paraíba, da lei complementar $n^{\circ} 123$, de 14 de dezembro de 2006, que institui o estatuto nacional da microempresa e da empresa de pequeno porte, e dá outras providências"; MP 127/2009 (PB) "Dispõe sobre a gratuidade do transporte coletivo intermunicipal para idosos e dá outras providências"

${ }^{22} \mathrm{Em}$ geral, vale a ressalva sobre a dificuldade de obtenção dos dados inerentes à tramitação das propostas legislativas no âmbito subnacional. No que tange às MPs, por exemplo, devido à falta de dados completos da tramitação das MPs, somente é possível constatar que na Paraíba há alguns casos de promulgação de substitutivos do legislativo à proposta original da MP, mas não é claro se houve alguma rejeição de MP. No Maranhão, há resultado para dois terços da MP.

23 Não custa lembrar que, relacionado à edição de medida provisória e também presente como prerrogativa do governador na tramitação de outras proposições legislativas, existe o pedido de solicitação de urgência que é outra forma de delegação de poderes do legislativo ao executivo.

24 Dados disponíveis para a edição de MPs e PLs até setembro de 2009. 
OPINIÃO PÚBLICA, Campinas, vol. 18, no 2, novembro, 2012, p. 255-277

apoio minoritário ou majoritário no legislativo estadual catarinense. Ou seja, governadores com apoio minoritário (Paulo Afonso - PMDB) ou majoritário (Esperidião Amim - PPB) na Assembleia Legislativa tiveram índices semelhantes de rejeição de MPs editadas. Em geral, a taxa de aprovação das MPs foi de $78 \%$. Ou seja, cerca de 2/3 das MPs foram convertidas em lei estadual. No mesmo período, o executivo aprovou $94 \%$ dos projetos de leis que apresentou ao parlamento catarinense. $O$ achado se confirma se compararmos o sucesso com os estados que não possuem a MP. Aqui, a taxa de sucesso dos projetos do executivo é superior a $85 \%$. Portanto, é claro que mesmo com a disponibilidade de um instrumento legislativo poderoso, os governadores de Santa Catarina não parecem possuir ganhos consideráveis na sua relação com o legislativo.

Tabela 6

Medidas Provisórias (MP) e Projetos de lei Ordinária (PL) propostos pelo Executivo em SC por ano e resultado final

(1990-2009)

\begin{tabular}{|c|c|c|c|c|c|c|c|c|c|}
\hline \multirow{2}{*}{ Governadores } & \multirow[b]{2}{*}{ Ano } & \multicolumn{4}{|c|}{ MP } & \multicolumn{4}{|c|}{ PL } \\
\hline & & Aprovadas & $\begin{array}{c}\text { Não } \\
\text { Aprovadas }\end{array}$ & Total & $\begin{array}{c}\% \\
\text { aprovação }\end{array}$ & Aprovadas & $\begin{array}{c}\text { Não } \\
\text { Aprovadas }\end{array}$ & Total & $\begin{array}{c}\% \\
\text { aprovação }\end{array}$ \\
\hline $\begin{array}{l}\text { Cassildo } \\
\text { Maldaner } \\
\text { (PMDB) }\end{array}$ & 1990 & 1 & 3 & 4 & $25 \%$ & - & - & . & . \\
\hline \multirow{4}{*}{$\begin{array}{l}\text { Vilson } \\
\text { Kleinubing } \\
\text { (PFL) }\end{array}$} & 1991 & 9 & 2 & 11 & $82 \%$ & . & . & . & . \\
\hline & 1992 & 20 & & 20 & $100 \%$ & . & . & . & . \\
\hline & 1993 & 14 & 4 & 18 & $78 \%$ & . & . & . & . \\
\hline & 1994 & 6 & & 6 & $100 \%$ & . & . & . & . \\
\hline \multirow{4}{*}{$\begin{array}{c}\text { Paulo Afonso } \\
\text { (PMDB) }\end{array}$} & 1995 & 5 & & 5 & $100 \%$ & 95 & 6 & 101 & $94 \%$ \\
\hline & 1996 & 4 & 4 & 8 & $50 \%$ & 109 & 2 & 111 & $98 \%$ \\
\hline & 1997 & & 2 & 2 & $0 \%$ & 142 & 4 & 146 & $97 \%$ \\
\hline & 1998 & 1 & & 1 & $100 \%$ & 170 & 30 & 200 & $85 \%$ \\
\hline \multirow{4}{*}{$\begin{array}{l}\text { Esperidião } \\
\text { Amim (PP) }\end{array}$} & 1999 & 6 & 2 & 8 & $75 \%$ & 113 & 4 & 117 & $97 \%$ \\
\hline & 2000 & 5 & 4 & 9 & $56 \%$ & 152 & 8 & 160 & $95 \%$ \\
\hline & 2001 & 6 & 2 & 8 & $75 \%$ & 190 & 7 & 197 & $96 \%$ \\
\hline & 2002 & 3 & 5 & 8 & $38 \%$ & 149 & 17 & 166 & $90 \%$ \\
\hline \multirow{4}{*}{$\begin{array}{c}\text { Luiz } \\
\text { Henrique } \\
\text { (PMDB) }\end{array}$} & 2003 & 4 & & 4 & $100 \%$ & 73 & 4 & 77 & $95 \%$ \\
\hline & 2004 & 1 & 1 & 2 & $50 \%$ & 126 & 13 & 139 & $91 \%$ \\
\hline & 2005 & 7 & & 7 & $100 \%$ & 146 & 6 & 152 & $96 \%$ \\
\hline & 2006 & 9 & 2 & 11 & $82 \%$ & 78 & 1 & 79 & $99 \%$ \\
\hline \multirow{4}{*}{$\begin{array}{c}\text { Luiz } \\
\text { Henrique } \\
\text { (PMDB) }\end{array}$} & 2007 & 10 & 2 & 12 & $83 \%$ & 136 & 9 & 145 & $94 \%$ \\
\hline & 2008 & 4 & & 4 & $100 \%$ & 53 & 3 & 56 & $95 \%$ \\
\hline & 2009 & 6 & 2 & 8 & $75 \%$ & . & . & . & . \\
\hline & TOTAL & 121 & 35 & 156 & $78 \%$ & 1732 & 114 & 1846 & $94 \%$ \\
\hline
\end{tabular}

Fonte: Banco de leis da Assembleia Legislativa de Santa Catarina.

A diferença mais significativa, nas legislaturas, é o número de MPs editadas. O governador Paulo Afonso (PMDB, 1995-98), minoritário na Assembleia, foi mais tímido que seu antecessor (Vilson 
RICCI, P.; TOMIO, F. O poder da caneta: a Medida Provisória no processo...

Kleinubing - PFL, 1991-94) e seu sucessor imediato (Espiridião Amin - PPB, 1999-2002), que eram apoiados pela maioria dos deputados estaduais. Sobretudo no final de seu mandato, ameaçado de impeachment, a edição de MPs pelo governador Paulo Afonso (PMDB) caiu bruscamente. O governo seguinte ao governo Amin, Luiz Henrique (2005-2009), PMDB, apoiado por coalizões majoritárias, também reduziu significativamente a quantidade de MPs editadas. Em geral, observa-se uma constante para os governos catarinenses: a taxa de aprovação dos PLs iniciados pelo executivo é superior à taxa de aprovação das MPs, independentemente do tamanho da coalizão de apoio. Fato que, de certa forma, indica o uso não estratégico das MPs pelo governador.

Passamos agora a tratar do conteúdo das MPs editadas. A maioria, em todas as legislaturas, tratava de questões relacionadas ao serviço público, matéria cuja competência de iniciar legislação é exclusiva do executivo (por exemplo, a contratação ou prorrogação de contratos de servidores públicos em caráter temporário e reajustes salariais). Quando o pedido era direcionado às áreas sociais (como a saúde), os parlamentares sempre aprovavam as MPs. Em outras áreas não era incomum a rejeição do decreto do governador. O segundo grupo relevante de MPs, também de competência exclusiva do executivo, tratava da realocação de verbas orçamentárias e fundos públicos, com resultados de votação semelhantes às MPs centradas na contratação de servidores públicos.

Assim, claramente, ao contrário de análises relacionadas ao governo federal, que vinculam o poder de decreto ao controle da agenda parlamentar, a capacidade de aprovação de projetos legislativos iniciados pelo executivo não foi determinada pelo direito de editar MPs. Como apontado por outros autores, mecanismos institucionais como poder de veto, solicitação de urgência e prerrogativas exclusivas de iniciar proposições legislativas em matérias financeiras e administrativas, em conjunto com o tamanho e a solidez da coalizão de apoio no parlamento estadual, são fatores com maior capacidade de determinação sobre os resultados legislativos em Santa Catarina (Tomı, 2006; CARREIRÃo e BorBA, 2006; CARREIRÃo e Perondi, 2009). Essa afirmação é reforçada por estudos semelhantes que constataram a grande capacidade de aprovação de legislação iniciada pelo executivo em outros parlamentos estaduais brasileiros (SANTOS, 2001; RICCI e TOMIO, 2012).

\section{Conclusão}

Este artigo buscou encontrar uma resposta para o uso diferente que a MP tem no Brasil quando se consideram os níveis federal e estadual. A argumentação se fundamentou na utilização do "poder de decreto" nos seis estados que delegam constitucionalmente esse instrumento legislativo aos governadores. Do ponto de vista teórico, conduzimos um experimento natural nos aproveitando do fato de que há seis casos que fazem uso da MP. A abordagem explorou as determinações dos mecanismos presentes na organização interna do processo decisório para a produção legislativa daqueles estados e também comparou o processo legislativo estadual ao federal, verificando se as hipóteses sobre o uso da MP são sustentáveis no processo decisório estadual. À guisa de conclusão, é possível oferecer pelo menos duas considerações.

Primeiro, a constituição de MPs nos estados parece resultar diretamente dos procedimentos legislativos presentes na Constituição Federal. Entretanto, apesar do "legado", a distribuição de 
OPINIÃO PÚBLICA, Campinas, vol. 18, no 2, novembro, 2012, p. 255-277

competências legislativas entre os entes federados legou aos estados, essencialmente, a atribuição de legislar: a) sobre a própria pública (orçamento, finanças, pessoal, patrimônio, organização, etc.), b) sobre aspectos normativos marginais das políticas públicas (educação, saúde, meio ambiente, etc.) e c) sobre aspectos significativos para execução autônoma dessas políticas (formação de fundos, contratação de pessoal e execução de obras que permitam implementar as políticas públicas). O primeiro e terceiro itens, apesar de aparentemente diferenciados quanto à finalidade legislativa, assemelham-se quanto à normatividade efetiva. Ou seja, tratam de assunto interno à máquina pública estadual. $\mathrm{O}$ segundo item legislativo decresce em relevância quanto mais a União legislar sobre cada política pública. Nesse sentido, tendo 1988 como marco inicial, conforme avança a produção legislativa federal, torna-se menos relevante (ou mais profundamente marginal) a competência estadual de normatizar as políticas públicas que executa. A atribuição de iniciativas privativas de proposição entre os atores políticos estaduais reproduziu o previsto para os poderes no âmbito federal. Dessa forma, toda a esfera normativa que trata da pública estadual é uma prerrogativa de proposição exclusiva dos governadores. Como esse é o centro do processo legislativo estadual, a legislação relevante que tramita nas Assembleias Legislativas é proposta pelo executivo. Portanto, independentemente da força política do governador e do tamanho da coalizão de apoio ao executivo, o processo legislativo estadual é fortemente dependente de proposições legislativas originadas no executivo, uma decorrência direta das prerrogativas legislativas exclusivas que detém esse ator político.

Disso deriva o segundo ponto a ser discutido. A delegação de MP ao executivo estadual poderia, em tese, ampliar o poder de agenda dos governadores. Entretanto, para que isso ocorra seria determinante a combinação de alguns aspectos variáveis nos estados nessa forma de delegação legislativa: a ausência de restrições ao motivo, tempo de vigência e vedações à edição de MP, além da normatização dos efeitos por lei ordinária (sujeito a sanção e ao veto). Como mostrado no artigo, há restrições complementares claras e definidas que aproximam os governadores dotados da MP aos seus similares sem essa delegação. Além do mais, é fato que o efeito jurídico das MPs editadas nos estados tende a se restringir à própria pública, predominantemente com leis sobre contratação e remuneração de servidores públicos e realocações orçamentárias. Claramente, o efeito dessas MPs precisaria ser mais bem investigado. Contudo, diante dos resultados expostos em Ricci e Tomio (2012), mostrando as taxas de sucesso elevadas para os projetos ordinários do executivo, é plausível supor que as mesmas proposições seriam aprovadas, em taxas semelhantes, caso fossem apresentadas como PLs com tramitação de urgência ou como Leis Delegadas. Neste sentido, as MPs nos estados constituem-se num instrumento privilegiado do executivo para legislar sobre matérias sem grande limitação de ser aprovada através dos instrumentos de delegação de poderes que, ordinariamente, os outros governadores possuem.

Posto nestes termos, nossa conclusão é que o instituto jurídico das MPs estaduais não deve ser visto como um instrumento a mais nas mãos do governador para se garantir frente um legislativo abdicante ou de tipo delegativo. Nos estados, diferentemente do âmbito federal, onde as MPs conferem ao Presidente ampla preponderância no processo decisório, este mecanismo não parece ter o mesmo 
RICCI, P.; TOMIO, F. O poder da caneta: a Medida Provisória no processo...

desempenho. Desse modo, as inúmeras críticas feitas ao instituto da MP no âmbito federal perdem sua relevância e substância efetivas quando se passa para o nível subnacional. Demonstrou-se infundada a posição do Ministro Carlos Velloso que, ao parecer favorável do STF reconhecendo a competência dos governadores em editar MPs em caso de relevância e urgência, afirmava que o STF "não devia conceder aos estados ou ao Distrito Federal a facilidade de edição de MPs que tantas preocupações trouxe a esta Corte". Como revelou esta análise, o efeito prático das MPs nos estados não é muito mais que um penduricalho institucional, restrito a poucas experiências estaduais e escassamente utilizado.

\section{Referências Bibliográficas}

ABRúcıo, F. Os barões da federação. São Paulo: Hucitec, 1998.

AmEs, B. Institutions and Politics in Brazil. Ann Arbor: University of Michigan Press, 2001.

Amorim Neto, O.; TAfner, P. "Governos de Coalizão e Mecanismos de Alarme de Incêndio no Controle Legislativo das Medidas Provisórias". Dados, vol.45, n¹, p. 5·38, 2002.

Ansolabehere, S.; Snyder, J.M.; Stewart, C. "Old Voters, New Voters, and the Personal Vote: using Redistricting to Measure the Incumbency Advantage". American Journal of Political Science, vol. 44, n 1, p. 17-34.

ARRETCHE, M. "The veto power of sub-national governments in Brazil: political institutions and parliamentary behaviour in the post-1988 period". Brazilian Political Science Review, vol.1, n², p. 40.73, 2007.

. "Continuidades e descontinuidades da Federação Brasileira: de como 1988 facilitou 1995". Dados, vol.52, n.2, p. 377.423, 2009.

BRASIL. Constituição: República Federativa do Brasil. Brasília, Senado Federal, 1988.

BRAGA, S. "A informatização dos legislativos brasileiros no início da $16^{a}$ Legislatura". Teoria \& Sociedade, vol. 14, p. $25 \cdot 54,2007$.

Cain, B.; Ferejohn, J.; FIorina, M. The Personal Vote: Constituency Service and Electoral Independence. Cambridge: Cambridge University Press, 1987.

CAREY, J.M.; Shugart, M. Executive decree Authority. Cambridge: Cambridge University Press, 1995.

. "Poder de decreto: Chamando os tanques ou usando a caneta?". Revista Brasileira de Ciências Sociais, vol. 13, n 37, p. 149-184, 1998.

CARREIRÃo, Y; BorBa, J. Os partidos na política catarinense: eleições, processo legislativo, políticas públicas. Florianópolis: Insular, 2006.

Carreirão, Y.; PerondI, E. "Disciplina e coalizões partidárias na Assembleia Legislativa de Santa Catarina (1999-2006)". Revista Brasileira de Ciências Sociais, vol. 24, n 71, p. 121-141, 2009.

Cox, J. The Efficient Secret: The Cabinet and the development of political parties in Victorian England. Cambridge: Cambridge University Press, 1989.

Cox, J.; MccubBins, M.D. Legislative Leviathan: party government in the House. Berkeley: University of California Press, 1993.

DA Ros, L. "Poder de decreto e accountability horizontal: dinâmica institucional dos tres poderes e medidas provisórias no Brasil pós-1988". Revista de Sociologia e Política, vol. 16, n` 31, p. 143-160, 2008.

DINıZ, E. Governabilidade, democracia e Reforma do estado: os desafios da Construção de uma Nova Ordem no Brasil dos anos 90. In: Dinız, E. (org). O desafio da democracia na América Latina, Rio de Janeiro: Iuperj, p. 162-186, 1996. 
OPINIÃO PÚBLICA, Campinas, vol. 18, n², novembro, 2012, p. 255-277

Dunning, T. "Improving Causal Inference: Strengths and Limitations of Natural Experiments". Political Research Quarterly, vol. 61, n², p. 282-293, 2008.

FIGUeIREDO, A.; LIMONGI, F. Executivo e legislativo na nova ordem constitucional. FGV: Rio de Janeiro, 1999.

. Instituições Políticas e Governabilidade. Desempenho do Governo e apoio Legislativo na democracia Brasileira. In: RANULfo, C.M.; SAÉZ, M.A. (orgs.). A Democracia Brasileira. Balanço e Perspectivas para o Século 21. Editora UFMG: Belo Horizonte, p. 147-198, 2007.

Gamper, A. "A Global theory of Federalism: The Nature and Challenges of a Federal State". German Law Journal, vol. 6, n०10, p. $1297 \cdot 1318,2005$.

Gerber, A.S.; Green, D.P. Field Experiments and Natural Experiments. In: Box-Steffensmeier, J.M.; Brady, H.E.; Collier, D. (eds.). Handbook of Political Methodology. New York: Oxford University Press, p. 357-381, 2008.

HUBer, J. Rationalizing parliament. Legislative Institutions and Party Politics in France. Cambridge: Cambridge University Press, 1996.

LAmounier, B. "Brazil at an impasse". Journal of Democray, vol. 5, n³, p. 72·87, 1994.

LIMONGI, F. "A democracia no Brasil: presidencialismo, coalizão partidária e processo decisório". Novos estudos Cebrap, $\mathrm{n}^{\circ} 76$, p. $17 \cdot 41,2006$

MACHIAVELI, F. "Medidas Provisórias: os efeitos não antecipados da EC32 nas relações entre executivo e legislativo". Dissertação de Mestrado em Ciência Política, Universidade de São Paulo, 2009.

MaInwaring, S. Rethinking Party Systems in the Third Wave of Democratization. The Case of Brazil. Stanford: Stanford University Press, 1999.

ORLOFf, A.S. The Politics of pensions: a comparative analysis of Britain, Canada, and the United States, 1880-1940. Wisconsin: The University of Wisconsin Press, 1993.

Pereira, C.; Power, T.; Rennó, L. "Agenda Power, Executive Decree Authority, and the Mixed Results of reform in the Brazilian Congress". Legislative Studies Quarterly, vol. 33, nº1, p. 5·33, 2008.

Pessanha, C. Relações entre os poderes executivo e legislativo no Brasil: 1946-1994. Tese de Doutorado, Usp, 1997.

"Poder executivo do legislativo no Brasil: o Decreto-lei e a Medida Provisória, 1965-1999. In: Seminário Internacional "Las instituciones em lãs Nuevas Democracias", Buenos Aires, 13 e 14 de abril de 2000.

Posner, D.N. "The Political Salience of Cultura Difference: Why Chewas and Tumbukas are allies in Zambia and adversaries in Malawi". American Political Science Review, vol. 98, n.4, p. 529.545, 2004

REICH, G. "Executive Decree Authority in Brazil: How Reactive Legislators Influence Policy", Legislative Studies Quarterly, vol. $27, n^{\circ} 1$, p. 5.31, 2002.

RIccl, P.; Tomı, F. "O governo local na experiência política brasileira. As performances legislativas das Assembleias estaduais". Revista de Sociologia e Política, vol. 20, n 41, 2012.

SANTOS, F. (org.). O poder legislativo nos estados: diversidade e convergência. FGV: Rio de Janeiro, 2001.

SANTOS, M.H.C. "Governabilidade, governança e democracia: criação de capacidade governativa e relações executivolegislativo no Brasil pós-constituinte". Dados, vol.40, n³, p. 335-376, 1997.

Shugart, M.S.; Haggard, S. Institutions and Public Policy in Presidential Systems. In: Haggard, S. MccubBinS, M.D. Presidents, Parliaments and Policy. Cambridge: Cambridge University Press, p. 64-102, 2001.

SouZA, C. "Federalismo, desenho constitucional e instituições federativas no Brasil pós-1988". Revista de Sociologia e Politica, vol. 24, p. 105-121, 2005;

Stepan, A. "Para uma Nova Análise Comparativa do Federalismo e da Democracia: Federações que Restringem ou Ampliam o Poder da Demos". Dados, vol. 42, n², p. 197-251, 1999.

Tomı, F.R.L. "The creation of municipalities after the 1988 constitution". Revista Brasileira de Ciências Sociais, vol.1, $\mathrm{n}^{\circ} 1,2005 \mathrm{a}$. 
RICCI, P.; TOMIO, F. O poder da caneta: a Medida Provisória no processo...

. "Autonomia Municipal e Criação de Governos Locais: a Peculiaridade Institucional Brasileira". Revista da Faculdade de Direito. Universidade Federal do Paraná, vol. 42, p. 103-120, 2005b.

. "Federalismo, municípios e decisões legislativas: a criação de municípios no Rio Grande do Sul”. Revista

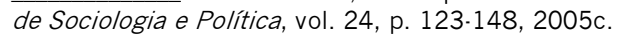

- Medidas provisórias, iniciativas e decisões legislativas no processo decisório estadual catarinense. In: CARREIRRÃo, Y; BORBA, J. (orgs.). Os partidos na política catarinense: eleições, processo legislativo, políticas públicas. Florianópolis-SC: Insular, 2006.

TOMIO, F.R.L. ORTOLAN, M. E CAMARgo, F. S. "Análise comparativa dos modelos de repartição de competências legislativas nos estados federados". Revista da Faculdade de Direito UFPR, vol. 51, p. 73·100, 2010.

Paolo Ricci - paolo.ricci@terra.com.br

Fabricio Tomio·fab_tom@hotmail.com

Submetido à publicação em janeiro de 2011.

Versão final aprovada em novembro de 2011. 